\title{
59. Zur Therapie infizierter Kontusionsherde der Lunge
}

\author{
J. Eisenbach* und A. Schmidt-Frankfurt a. M.
}

\author{
The Treatment of Infected Contusions of the Lung
}

Summary. Infection of contused area of the lung can be a dangerous complication in view of the other severe injuries which may exist at the same time, and rapid and adequate therapeutic measures are indicated. Of 266 patients with severe blunt chest injuries treated at the Surgical University Clinic, Frankfurt, between 1965 and 1970, this complication arose in 19 cases, mainly in the form of a lobar or bronchial pneumonia. Treatment with antibiotics must be started at once. There is no time to wait for the results of bacteriological sensitivity tests. In our patients, the combination of an intravenous slow drip containing $2 \times 4 \mathrm{~g}$ of Cephalotin and $2 \times 40 \mathrm{mg}$ of Gentamycin per day was effective in providing as broad an antibiotic spectrum as possible. Alternatively, in patients without tracheotomy, treatment with $2 \mathrm{~g}$ of tetracycline daily could be considered. In addition to antibiotic treatment aid the usual anti-pneumonia measures (Physiotherapy, oxygen, cardiac and circulatory stimulants, analgesics), a careful bronchial-toilette consisting of suction drainage is of the greatest importance. In cases with severe dyspnoea and unstable thorax one must not delay tracheotomy and institute artificial respiration as soon as possible. Further measures which may become necessary are: removal of a haemopneumothorax by Bülau-Drainage, surgical stabilization of the chest wall in cases of extensive fractures of ribs.

By using these methods of treatment it is usually possible to overcome infections of the contused areas of the lung. The fatal cases which, however, still occur are mainly due to irreparable skull and cerebral traumas which are also present.

Zusammenfassung. Die Infektion eines Kontusionsherdes der Lunge stellt wegen der meist gleichzeitig bestehenden, schweren anderweitigen Verletzungen eine lebensbedrohliche Komplikation dar, die schnelles und gezieltes Handeln erfordert. Bei 266 schweren stumpfen Thoraxtraumen (Chirurgische Universitätsklinik Frankfurt a. M. 1965-1970) trat das Krankheitsbild 19 mal in Erscheinung, vorwiegend in Form einer Lobär- oder Bronchopneumonie. Zur Therapie sind sofort Antibioticagaben notwendig. Das Ergebnis der bakteriologischen Resistenzbestimmung kann nicht abgewartet werden. Zur Erzielung eines möglichst breiten Wirkungsspektrums hat sich die Kombinationsbehandlung mit $2 \times 4 \mathrm{~g}$ Cephalotin als i.v. Dauertropfinfusion in Kombination mit $2 \times 40 \mathrm{mg}$ Gentamycin pro die bewährt. Alternativ käme insbesondere bei Kranken ohne Tracheotomie eine Behandlung mit $2 \mathrm{~g}$ Tetracyclin täglich in Betracht. Neben der Antibioticabehandlung und den üblichen antipneumonischen Maßnahmen (physikalische Therapie, Anreicherung der Atemluft mit $\mathrm{O}_{2}$, Herz-Kreislaufmittel und Analgetica) ist die gezielte Bronchialtoilette durch endoskopische Absaugung von größter Bedeutung. Bei schwerer Dyspnoe und Instabilität des Thorax sollte mit der Tracheotomie und der assistierten Beatmung nicht gezögert werden. Weitere Maßnahmen wie die Beseitigung eines Hämatopneumothorax durch Bülau-Drainage oder die operative Stabilisierung der Brustwand bei ausgedehnten Rippenserienstïckfrakturen können erforderlich werden. - Mit diesen Behandlungsmaßnahmen läßt sich die Infektion von Kontusionsherden der Lunge im allgemeinen gut beherrschen. Die dennoch aufgetretenen Todesfälle gehen vorwiegend zu Lasten eines gleichzeitig bestehenden irreparablen Schädel-Hirntraumas. 